\title{
DESIGN OF A DETECTING MODULE BASED ON A SINGLE-SIDED SILICON PHOTOSENSOR ARRAY WITH SCINTILATORS
}

\author{
S.K. Kiprich, N.I. Maslov, I.N. Shlyahov \\ National Science Center “Kharkov Institute of Physics and Technology”, Kharkiv, Ukraine
}

A design of a detecting module based on a silicon front side illuminated single-sided photosensor array with scintillators has been developed. The array is made on wafers with a diameter of $100 \mathrm{~mm}$ from high-resistance Ntype silicon with a specific resistance of $5 \ldots 10 \mathrm{kOhm} \cdot \mathrm{cm}$, lifetime of minority charge carriers $\tau>1000 \mu \mathrm{s}$ and orientation $\langle 100\rangle$. The elimination of shielding of the photosensitive surface of the array by electrical connection elements is ensured by the use of aluminum-polyimide microcables provided that they are placed on the front side of the array in the gaps between the scintillators. The installation of front-end electronics on the board on the reverse side of the array within the array area allows to create a detecting module of compact size with minimal loss of effective recording area. A module with 64 dete ction cells located in a pitch of $4.1 \mathrm{~mm}$ does not exceed an area of $35 \times 35 \mathrm{~mm}$.

PACS: 28.20.07.05.Tp

\section{INTRODUCTION}

Devices for visualizing the results of radiation studies use a large number of gamma radiation detectors, each of which contains a scintillator for converting gamma radiation into light and a photosensitive detector for converting light into an electrical signal.

Arrays of detectors are formed in the form of twodimensional arrays based on silicon planar detectors. The design of the arrays can provide registration of radiation either the front side of the silicon detectors, or the back side. Both of these options have their advantages and disadvantages.

Arrays operating in the frontal irradiation mode usually have lower quantum efficiency than arrays operating in the illumination mode on the back side. This is due to the fact that the electrically conductive tracks on the array surface, which are necessary to transmit the signal from all the array cells, reduce the area of the active photosensitive region on the front side and increase the spurious capacitance between the signal circuits and the array, which leads to a decrease in the energy resolution. Therefore, arrays with illumination on the back side are more often used when it is necessary to improve photosensitivity, signal-to-noise ratio, spatial and energy resolution [1 - 4].

However, the manufacturing technology of doublesided arrays of silicon detectors is more complicated than single-sided ones. In addition, the design of the modules based on a single-sided array allows compactly placing the front-end electronics, which are particularly sensitive to cross-talk, in close proximity to the array, namely, from the back side of the array within the array area, while on the front side it contains all the electrical connections of the detecting cells and scintillators.

In order to prevent shielding of the photosensitive region of the frontally illuminated silicon detectors array by elements of electrical connections in the developed design of the detecting module, it is proposed to transmit signals from the detection cells to the inputs of a multi-channel charge-sensitive preamplifier (CSA) using flat double-layer non-adhesive aluminumpolyimide microcables.

Similar microcables were used in the ALICE Internal Tracking System at CERN to create barrels of sili- con drift and silicon microstrip detectors [5 - 7]. Microcables provided a large number of electrical connections under severe restrictions on the free space and radiation length of the materials used. At the same time, they showed high reliability and ease of use.

The advantages of microcables include also their elasticity, high mechanical strength compared to wire connections, low resistance of conductive tracks ( $\rho_{\mathrm{Al}}=$ $\left.2.67 \cdot 10^{-8} \mathrm{Ohm} \cdot \mathrm{m}\right)$, high resistance of the insulating base $\left(\rho_{\mathrm{PI}}=10^{14} \ldots 10^{15} \mathrm{Ohm} \cdot \mathrm{m}\right)$ and low dielectric constant $(\varepsilon=3.5)$. In addition, microcables allow individual design to be applied to specific connected objects and allow the use of standard connection methods, namely, ultrasonic bonding [8 - 10].

\section{ARRAY OF SILICON DETECTORS}

In the framework of the STCU project № 9903, the development of the detector array was carried out, manufactured on double-sided polished wafers with a diameter of $100 \mathrm{~mm}$ from high-resistance N-type zone melting silicon with a specific resistance of $5 \ldots 10 \mathrm{kOhm} \cdot \mathrm{cm}$, lifetime of minority charge carriers $\tau>1000 \mu$ s and orientation $<100>$. All structures of the array elements, including the implantation, isolation, passivation, polysilicon and conducting elements zones, are formed on the front side of the plate, the back side of the wafer contains only $\mathrm{N}+$ contact. The arrangement of the detecting cells of the array and the enlarged image of a single cell are shown in Fig. 1.

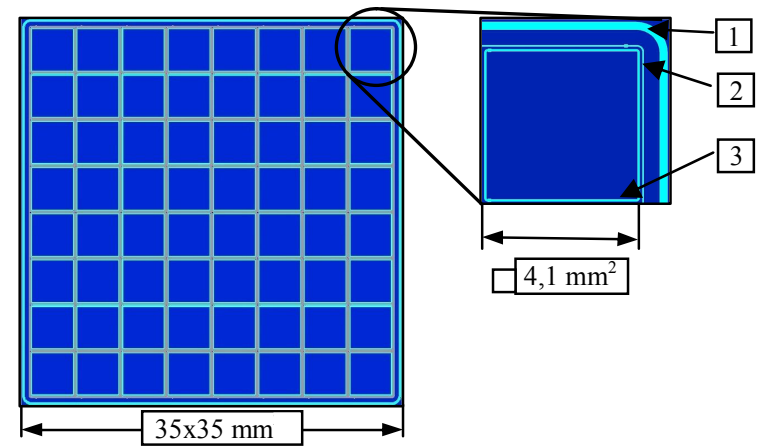

Fig. 1. The array of silicon detectors and a single detecting cell, where 1 - the $N+$ ring;

2 - the protective ring; 3 - the ring of the active region 
The array contains 64 cells of single detectors located in 8 rows and 8 columns. The pitch of cells on both axes is $4.1 \mathrm{~mm}$. The overall size of the array is $35 \times 35 \mathrm{~mm}$. The array contains one common $\mathrm{N}+$ ring and one protective $\mathrm{P}+$ ring that surround all single detecting cells, as well as 64 rings of the active region of the cells.

The material of conductors and pads is aluminum, the size of pads for connecting electrical circuits is $110 \times 140 \mu \mathrm{m}$.

The array is manufactured using adapted technology based on standard manufacturing processes of CMOS electronics.

\section{DESIGN OF DETECTING MODULE}

The design of the detecting module based on the developed array includes a array of silicon detectors, scintillators, flat aluminum-polyimide microcables and a ceramic board with multi-channel CSA and a small-sized multi-pin connector for connecting to the main amplifier of the detection system located outside the module.

The mechanical basis of the module is a ceramic board of equal size to the silicon array, on the working side of which are multi-channel CSA, and on the back side there is an array of silicon detectors with scintillators and microcables. The use of a ceramic board (hereinafter, the board) is due to a higher surface resistance compared to the printed circuit board, which is required to obtain a high energy resolution. Scintillators in the form of prisms with a square cross-section, having a reflective coating on all faces, are glued with optically transparent glue to all the detecting cells of the array. The use of scintillators from CsI (Tl) allows the detection of gamma radiation with energies from $40 \mathrm{keV}$ to $1.0 \mathrm{MeV}$.

The module uses two types of microcables - wraparound and signal microcables. Four wrap-around microcables connect the power and ground circuits between the corresponding pads of the board and the array located on opposite planes. The signal microcables providing electrical connection of all the detecting cells of the array with the inputs of the CSA on the board have a more complex shape due to bends in various planes to optimize their laying. Moreover, above the photosensitive region of the array, the microcables are located in the plane perpendicular to the array surface in the gaps between the scintillators (Fig. 2).

This arrangement of microcables helps to solve two problems - eliminating the screening of the photosensitive areas of the matrix and a significant reduction in spurious capacitance between the signal traces of the microcable and the array.

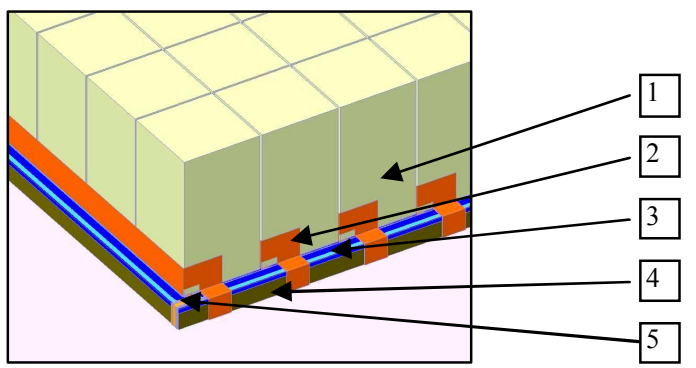

Fig. 2. The main components of the detecting module, where 1 -scintillators; 2 -signal microcables; 3 -an array; 4 -ceramic board; 5-wrap-around microcables
The microcables are made up from FDI-A-24 lacquer-foil dielectric where the dielectric base is the polyimide film of $10 \mu \mathrm{m}$ thick, and aluminum traces of $14 \mu \mathrm{m}$ thick that are used as conductors [7].

In the area where the aluminum terminals of the cable are bonded to the pads, the polyimide base has openings, providing access to the terminals from two sides. The connection of the aluminum microcable terminals to the pads is carried out by the method of ultrasonic bonding. The elasticity of microcables allows them to be bent with a minimum bending radius without damaging the conductive and dielectric elements. The configuration of the dielectric base, the location of the traces, as well as the connection points of the microcable traces are designed taking into account the relative position of the connected elements and optimize the trajectory of laying the microcables.

Fig. 3 shows an image of a signal microcable for transmitting signals from one row of detecting cells. The design of the signal microcable is universal for all rows of detecting cells.

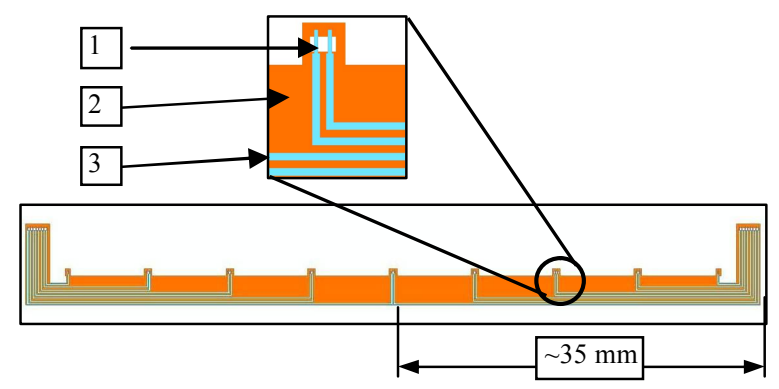

Fig. 3. Signal microcable, where 1 -terminals for connection to the array; 2 -polyimide base;

$$
3 \text {-aluminum traces }
$$

The width of the conductive traces of the microcable is $100 \mu \mathrm{m}$, the gap between the traces is also equal to $100 \mu \mathrm{m}$. The width of the leads in the bonding area is $60 \mu \mathrm{m}$.

Due to the fact that the microcable is used in the front-end circuit of the CSA, its influence on the noise parameters and the energy resolution of the detection unit is very important. To estimate the influence of parasitic cable parameters, an equivalent input circuit diagram is presented, shown in Fig. 4.

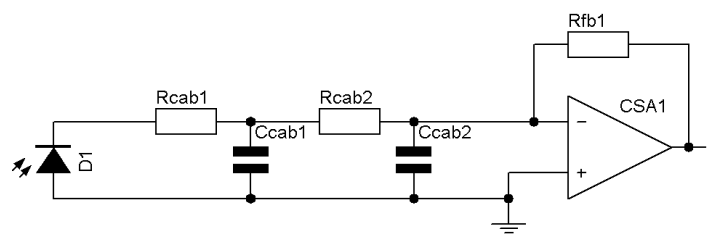

Fig. 4. Equivalent layout of the front-end electronics of the detecting module

Resistors $\mathrm{R}_{\mathrm{cab} 1}$ and $\mathrm{R}_{\mathrm{cab} 2}$ simulate the active resistance of cable traces, the order of magnitude of their resistance is in the range of $1 \ldots 10 \mathrm{Ohms}$ and their noise can be neglected. Capacitors $\mathrm{C}_{\mathrm{cab} 1}$ and $\mathrm{C}_{\text {cab2 }}$ simulate the distributed cable capacitance between signal and ground circuits. Due to the fact that the microcable is located vertically to the array surface, the spurious capacitance between the signal circuits and the array substrate can be neglected. Thus, the minimum possible structural capacity between the array and CSA is obtained. To esti- 
mate the influence of spurious cable capacitance, a series of measurements of the spectral characteristics of single silicon planar detectors with various options for the capacitance of the input circuits was carried out, the results of which are shown in Figs. 5-7.

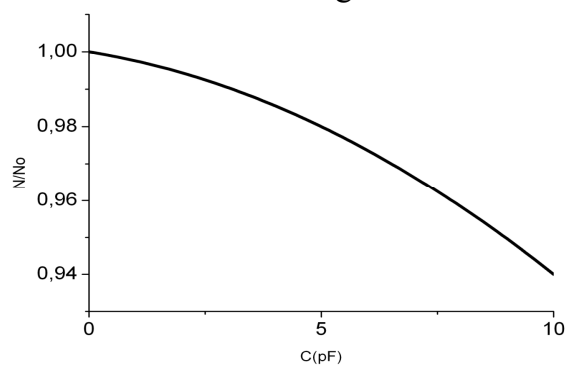

Fig. 5. Relative change in signal amplitude depending on the capacity of the signal microcable

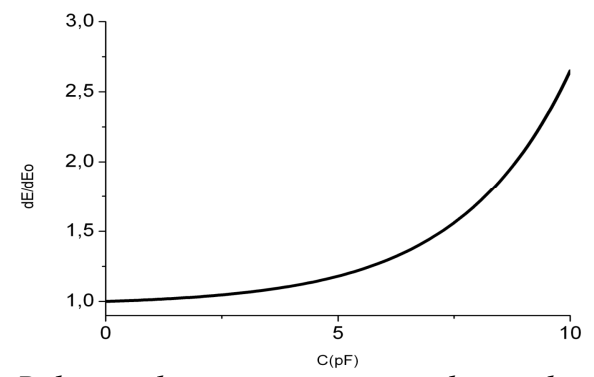

Fig. 6. Relative change in energy resolution depending on the capacity of the signal microcable

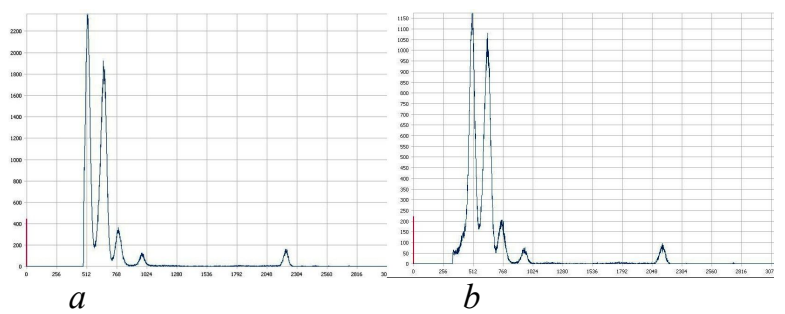

Fig. 7. Radiation spectra of ${ }^{241} \mathrm{Am}$ : $a$-without a microcable, $d E=1.19 \mathrm{keV} ; b-$ with a microcable of $50 \mathrm{~mm}$ long, $d E=1.4 \mathrm{keV}$

It can be seen from the graphs that the capacitance of the signal microcable of up to $5 \mathrm{pF}$ weakly affects the signal amplitude and the energy resolution of the detector. Taking into account the fact that microcables with the indicated dimensions have a linear capacitance of the order of $0.5 \ldots 0.6 \mathrm{pF} / \mathrm{cm}$, microcables with a length of up to $10 \mathrm{~cm}$ can be used without noticeable deterioration of the module's characteristics. In the proposed module design, the longest current traces of the microcable do not exceed $45 \mathrm{~mm}$.

\section{ASSEMBLY OF THE DETECTING MODULE}

The assembly sequence of the proposed module has its own characteristics, allowing to take into account and most effectively use the mechanical and electrical properties of the component elements of the module.

At the initial stages, the CSA is mounted on the working surface of the board and the parameters of the board are tested. Then the array is glued to the back surface of the board and the installation of the wraparound cables is carried out, namely gluing the cables and bonding the microcable terminals to the pads of the array and the board (Fig. 8).

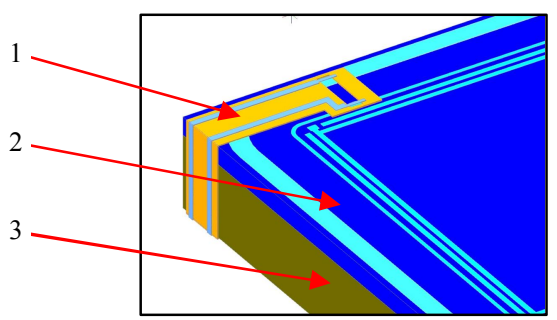

Fig. 8. Installation of a wrap-around microcable, where 1 -wrap-around microcable; 2 - an array; 3 - a board

The next step is the placement of signal microcables on the array surface, alignment and bonding the terminals of signal microcables to the pads of the array active regions, as well as gluing small sections of signal microcables to the array in the area of bonding. At this stage of the assembly, there is only one open row of cells on the array surface, the remaining rows are partially or completely covered by signal microcables (Fig. 9).

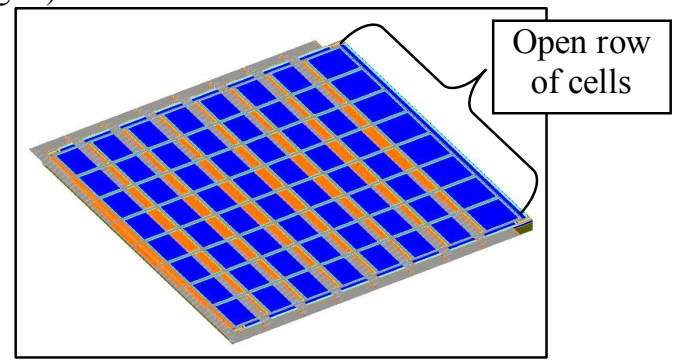

Fig. 9. Placement of signal microcables on the array

Then, the first row of scintillators is glued to the open cells of the array and the signal microcable attached to this row of cells is folded at an angle of $90^{\circ}$ to the array surface. After this step, access to the second row of array cells opens, that allows gluing the second row of scintillators (Fig. 10).
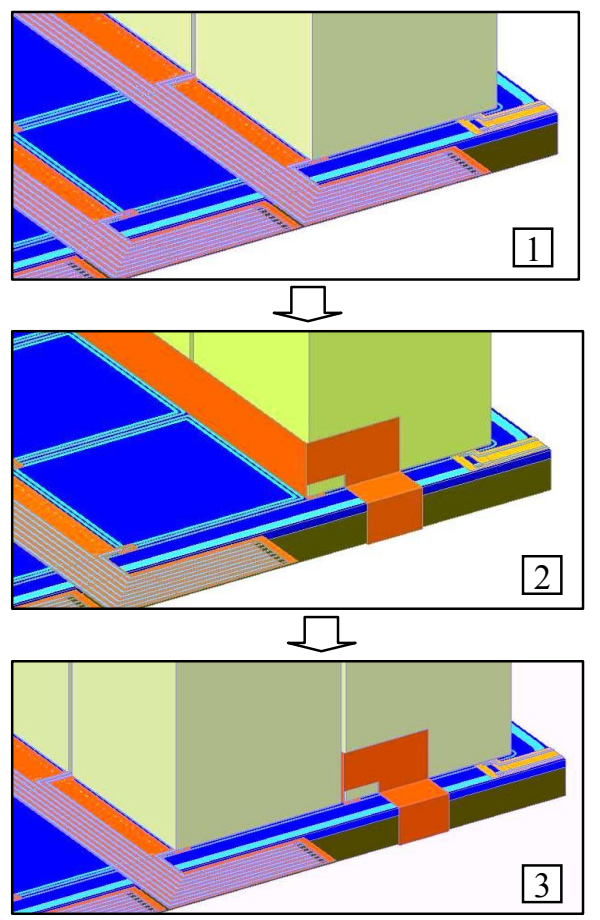

Fig. 10. Steps for mounting scintillators and signal microcables on an array, where 1 -gluing the first row of scintillators; 2 -folding the first microcable;

3 - gluing the second row of scintillators 
By repeating the steps described above for gluing scintillator rows and folding microcables in this way, scintillators and signal microcables are mounted on the entire surface of the array. To facilitate the installation process, microcables after bending are glued to the side surfaces of scintillators. The small thickness of the microcables $(\mathrm{d}=24 \mu \mathrm{m})$, that are located in the gaps between the rows of scintillators in a plane perpendicular to the array surface, practically does not reduce the effective recording area. Fig. 11 shows the assembled detecting module based on a single-sided frontally illuminated photosensor array with scintillators.

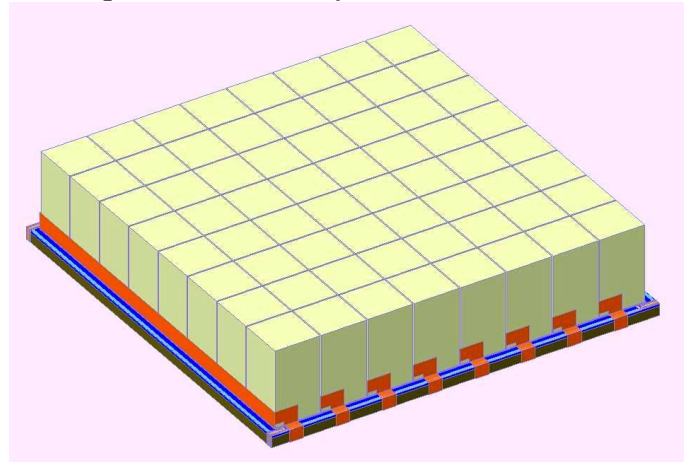

Fig. 11. Detecting module based on a single-sided frontally illuminated photosensor array with scintillators

Elasticity and a sufficiently high mechanical strength allow folding of microcables with minimum folding radii and wrapping them around the side face of the array on the working surface of the board, where the cable terminals are also connected to the pads of the board by ultrasonic bonding. Gluing microcables to the side surfaces of scintillators, the array, and the board in all areas of the laying of microcables increases the mechanical strength of the assembled module.

\section{ELECTRONICS OF THE DETECTING MODULE}

One of the requirements for a detecting module is the possibility of its operation in the spectrometric mode, with the highest achievable energy resolution. One of the possible ways to achieve maximum energy resolution can be the separation of the readout electronics into two functionally complete stages - the input low-noise stage of the control system and the main amplification stage. The input stage of the CSA is a part of the module on the working side of the board, and with the help of a small multi-pin connector and cable it is connected to the main amplifier of the detection system located outside the module.

The electrical circuit of the front-end electronics of the CSA located on the board is shown in Fig. 12.

The signal transmits to the input pads of the CSA on the board, to which microcables coming from the array are connected, and then the signal is amplified by lownoise field-effect transistors T1-64 and transmitted to the connector Bu1. Resistors R1-64 are the feedback resistors of the CSA.

The use of discreet components, i.e. field-effect transistors that are not integrated on a common crystal of a multi-channel CSA, allows optimizing the signalto-noise ratio and the energy resolution of the detecting module. Due to the use of SMD elements (transistors in the SOT-23 package, SMD resistors 0603), front-end electronics are placed on a board whose area does not exceed the area of the array.

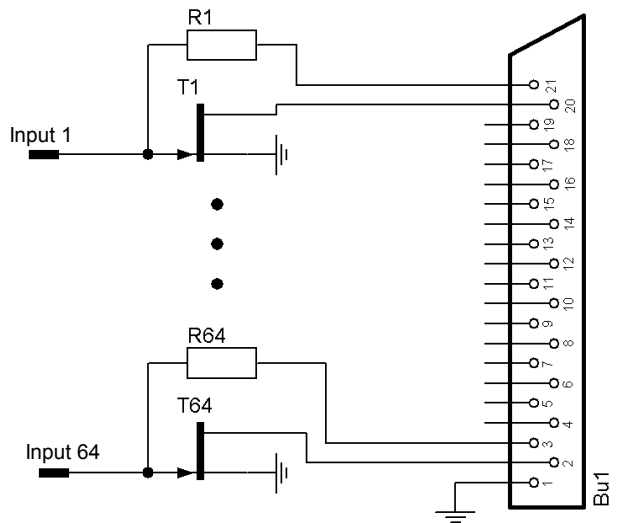

Fig. 12. Schematic diagram of the front-end electronics of the module

An alternative to the CSA using discrete components can be the use of multi-channel integrated circuits, for example IDE1140 from IDEAS $[11,12]$.

Such design solutions allows to create compact detecting modules and use them when creating arrays of recording devices of large sizes. The design of the module does not contain protruding parts. That makes it possible to place an array of such modules in one plane with minimal gaps between them to minimize losses of the effective recording area.

\section{CONCLUSIONS}

A design of a detecting module based on a silicon single-sided photosensor array with scintillators has been developed. The described design makes it possible to increase the detection efficiency of gamma radiation, which is necessary for image visualization during radiation studies. The location of the microcables in a plane perpendicular to the plane of the array allows electrical connections of all the detecting cells and, thus, eliminates the screening of the photosensitive surface of the array. The use of a single-sided silicon array of photosensors reduces the cost of the detecting module in comparison with the use of a double-sided array.

A module with 64 detection cells located in a pitch of $4.1 \mathrm{~mm}$ does not exceed an area of $35 \times 35 \mathrm{~mm}$.

The modules can be used to create large-area detection systems for medical use, including scanners for positron emission tomography.

The publication contains the results of studies conducted with grant support from the STCU project № 9903.

\section{REFERENCES}

1. https://www.hamamatsu.com/resources/pdf/ssd/e09 handbook_xray_detectors.pdf

2. G.J. Gruber. A Compact 64-Pixel CsI(Tl)/Si PIN Photodiode Imaging Module With IC Readout // IEEE Transactions on Nuclear Science. 2002, v. 49, № 1, p. 147-152.

3. W.-S. Choong et al. A Compact 16-Module Camera Using 64-Pixel CsI(Tl)/Si P-I-N Photodiode Imag- 
ing Modules // IEEE Transactions on nuclear science. 2002, v. 49, № 5, p. 2228-2235.

4. Backside illuminated photodiode array. Pat. US 2002/0020846A1, Feb. 21, 2002.

5. The ALICE Collaboration, K. Aamodt et al. The ALICE Experiment at the CERN LHC. 2008 JINST 3 S08002, 245 p.

(https://jinst.sissa.it/LHC/ALICE/2008_JINST_3_S 08002.pdf).

6. V. Borshchov, A. Boiko, S. Kiprich, et al. Aluminium Microcable Technology for the Alice Silicon Strip Detector: A Status Report // 8th Workshop on Electronics for LHC Experiments, Colmar, France. 2002, p.144-149.

7. M. Bregant et al. Assembly and validation of the ALICE silicon microstrip detector // Nuclear Instruments and Methods in Physics Research, Section A: Accelerators, Spectrometers, Detectors and As- sociated Equipment. 2007, v. 570, Issue 2, p. 312316.

8. S.K. Kiprich. Investigation of ultrasonic bonding process of aluminum microcables with pitch less than 100 um // Technology of Instrument Making. 2003, Issue 1, p. 10-13.

9. A.V. Vorobyev, V.D. Zhora. Flexible foiled dielectrics: classification and analisys of ways for application and improvement // Tekhnologiya i Konstruirovanie v Elektronnoi Apparature. 2014, № 4, p. 5661 (in Russian).

10. https://ideas.no/products/ide1140/

11. Ju.V. Tuboltsev et al. Position-sensitive spectrometric module for registration of ionizing radiation by semiconductor strip detectors // Technical Physics Letters. 2018, v. 44, № 23, p. 56-62.

Article received 04.03.2020

\section{КОНСТРУКЦИЯ ДЕТЕКТИРУЮЩЕГО МОДУЛЯ НА ОСНОВЕ ОДНОСТОРОННЕЙ КРЕМНИЕВОЙ ФОТОСЕНСОРНОЙ МАТРИЦЫ СО СЦИНТИЛЛЯТОРАМИ}

\section{С.К. Киприч, Н.И. Маслов, И.Н. Шляхов}

Разработана конструкция детектирующего модуля на основе кремниевой фронтально облучаемой односторонней фотосенсорной матрицы со сцинтилляторами. Матрица изготавливается на пластинах диаметром 100 мм из высокоомного кремния N-типа с удельным сопротивлением 5..10 кОм·см, временем жизни неосновных носителей заряда $\tau>1000$ мкс и ориентацией $<100>$. Исключение экранирования фоточувствительной поверхности матрицы элементами электрической коммутации обеспечивается за счет использования алюминий-полиимидных микрокабелей при условии размещения их на фронтальной стороне матрицы в зазорах между сцинтилляторами. Установка предварительных каскадов усиления сигнала на плате с обратной стороны матрицы в пределах площади матрицы позволяет создать детектирующий модуль компактного размера с минимальными потерями эффективной площади регистрации. Модуль с 64-мя детектирующими ячейками, расположенными с шагом 4,1 мм, не превышает площадь $35 \times 35$ мм.

\section{КОНСТРУКЦІЯ ДЕТЕКТУЮЧОГО МОДУЛЯ НА ОСНОВІ ОДНОСТОРОННЬОЇ КРЕМНІЄВОЇ ФОТОСЕНСОРНОЇ МАТРИЦІ З СЦИНТИЛЯТОРАМИ}

\section{С.К. Кіпріч, М.І. Маслов, І.М. Шляхов}

Розроблено конструкцію детектуючого модуля на основі кремнієвої фронтально опромінюваної односторонньої фотосенсорної матриці з сцинтиляторами. Матриця виготовляється на пластинах діаметром 100 мм 3 високоомного кремнію N-типу з питомим опором 5..10 кОм·см, часом життя неосновних носіїв заряду $\tau>1000$ мкс і орієнтацією $<100>$. Відсутність екранування фоточутливої поверхні матриці елементами електричної комутації забезпечується за рахунок використання алюміній-поліімідних мікрокабелів за умови розміщення їх на фронтальній стороні матриці в зазорах між сцинтиляторами. Установка попередніх каскадів посилення сигналу на платі із зворотного боку матриці в межах площі матриці дозволяє створити детектуючий модуль компактного розміру з мінімальними втратами ефективної площі реєстрації. Модуль 3 64-ма детектуючими комірками, розташованими з кроком 4,1 мм, не перевищує площу $35 \times 35$ мм. 